\title{
Defenses of Caribbean sponges against invertebrate predators. II. Assays with sea stars
}

\author{
Brett Waddell, Joseph R. Pawlik* \\ Biological Sciences and Center for Marine Science Research, University of North Carolina at Wilmington, Wilmington, \\ North Carolina 28403-3297, USA
}

\begin{abstract}
Sea stars are dominant predators in many marine habitats, and spongivory by sea stars has been documented from polar seas to the tropics. Feeding assays of whole tissue and artificial foods containing organic extracts, spicules, and spiculated skeleton of sponges were performed with the Caribbean sea stars Echinaster echinophorus (from the Bahamas) and Echinaster sentus (from Florida, USA) to determine whether sponge secondary metabolites or skeletal constituents affect feeding by sea stars. Whole tissue assays of 6 species of mangrove sponges yielded similar preference hierarchies for both sea star species: for E. echinophorus, Tedania ignis = Haliclona hogarthi Ircinia felix = Dysidea etheria $>$ Chondrilla nucula $=$ Chondrosia collectrix; for E. sentus, T. ignis $=H$. hogarthi $>I$. felix $=D$. etheria $=C$. nucula $=C$. collectrix. Whole tissue assays of 5 species of reef sponges yielded identical hierarchies for both E. echinophorus and E. sentus: Geodia neptuni > Callyspongia vaginalis > Amphimedon compressa $=$ Ectyoplasia ferox $=$ Agelas clathrodes. Crude organic extracts of the same 6 mangrove sponge species were assayed, and only the crude organic extracts of Dysidea etheria deterred feeding by $E$. echinophorus. Extracts of $I$. felix, which consistently deterred both fishes and hermit crabs in previous studies, did not deter E. echinophorus. Extracts of the same reef sponge species were assayed, and only $A$. clathrodes, $E$. ferox and $A$. compressa deterred feeding by $E$. echinophorus. In whole tissue assays with $E$. sentus of chemically non-defencled species (sponges that yielded organic extracts palatable to E. echinophorus) from both reef and mangrove habitats, all species were consistently preferred over $C$. nucula. The preferences of $E$. sentus for chemically nondefended species did not correlate with sponge nutritional or skeletal content, suggesting that other characteristics of these sponges influence sea star preferences. Spicules from 5 species of reef sponges (G. neptuni, C. vaginalis, A. clathrodes, E. ferox, and A. compressa) and 3 species of mangrove sponges (T. jgnis, H. hogarthi, and $C$. nucula), and whole sponge skeleton from 4 species of mangrove sponges ( $T$ ignis, I. felix, C. nucula, and C. collectrix) did not deter feeding by E. echinophorus. These results, when considered with the data from previous studies employing fishes and hermit crab assays, further illustrate the importance of secondary metabolites as antipredatory defenses for Caribbean sponges.

KEY WORDS: Sponge - Predation - Sea stas Chemical defense - Caribbean - Chemical ecology
\end{abstract}

\section{INTRODUCTION}

Sea stars often play a significant role as predators in marine ecosystems (Feder \& Christiansen 1966, Jangoux 1982). Spongivory has been reported for many species of sea stars (reviewed in Sloan 1980). Predation by sea stars may affect sponge distributions in some systems. Dayton

\footnotetext{
•Corresponding author. E-mail: pawlikj@uncwil.edu
}

et al. (1974) reported that spongivory by the sea stars Perknaster fuscus antarcticus and Acodontaster conspicuus limited the abundance of the dominant spacecompetitor in the sponge community at McMurdo Sound, Antarctica (see McClintock \& Baker 1998). Predation during the summer months by the North Atlantic sea star Henricia sanguinolenta was shown to weaken the tissue of the finger sponges Isodictya spp. in the Gulf of Maine, leading to increased tissue loss when high wave action occurred in the fall and winter (Sheild \& 
Witman 1993). In the Caribbean, sponge feeding by the common sea star Oreaster reticulatus has been proposed to prevent storm-displaced reef sponge fragments from colonizing seagrass beds (Wulff 1995). Spongivory by several species of Caribbean sea stars, including Echinaster echinophorus (Ferguson 1969), O. reticulatus (Thomas 1960, Scheibling 1982, Wulff 1995), and Echinaster sentus (Hendler et al. 1995) has been reported, but no study to date has investigated whether sponge antipredatory defenses influence the feeding preferences of these spongivorous sea stars

Tropical marine sponges are rich in secondary metabolites (Scheuer 1990, Faulkner 1998), and purified sponge secondary metabolites have been shown to possess antifeedant properties (Pawlik et al. 1988, Paul 1992, Pawlik 1993, Albrizio et al. 1995). Crude organic extracts of Caribbean sponges deter feeding by the generalist reef fish Thalassoma bifasciatum (Pawlik et al. 1995) and by the common reef hermit crab Paguristes punticeps (Waddell \& Pawlik 2000, in this issue). Skeletal components of sponges have also been proposed to deter feeding by potential sponge predators. Inorganic siliceous spicules have been hypothesized to provide physical defense by irritating the mouthparts and guts of predators (Randall \& Hartman 1968, Hartman 1981, Wainwright et al. 1982). However, spongivores such as fishes (Randall \& Hartman 1968, Dunlap \& Pawlik 1996, 1998), turtles (Meylan 1988), and sea urchins (Bierenheide et al. 1993) consumed spicules without apparent ill effects, and spicules were found to be nondeterrent to generalist predatory reef fishes (Chanas \& Pawlik 1995, 1996) and to hermit crabs (Waddell \& Pawlik 2000). The internal skeleton of sponges made of the proteinaceous fibers called spongin is also proposed to protect sponges from predation because it is hard to digest, thereby potentially reducing the nutritional quality of the sponge (Bjorndal 1990, Meylan 1990). However, whole sponge skeleton embedded in an artificial food matrix did not deter feeding by generalist predatory fishes (Chanas \& Pawlik 1996) or by hermit crabs (Waddell \& Pawlik 2000). In studies of spongivory by Antarctic sea stars, sponge secondary metabolites affected feeding preferences of sea stars, while spicules and indigestible protein present in sponge tissue did not (Dayton et al. 1974, McClintock 1987, McClintock et al. 1994), presumably because sea stars can digest away the cellular material of sponges, leaving behind the indigestible skeleton (Dayton et al. 1974, Wulff 1995).

To determine whether sponge secondary metabolites or sponge skeletal components (spicules and proteinaceous spongin) affect feeding by sea stars, assays were performed with the spongivorous Caribbean sea stars Echinaster (=Othilia) echinophorus and Echi- naster (= Othilia) sentus. Assays of whole sponge tissue from mangrove and reef sponges were performed to determine the preferences of Echinaster spp. for these sponges. Assays of sponge crude organic extracts, spicules, and whole sponge skeleton were performed to determine whether any of these characteristics influence sea star preferences.

\section{MATERIALS AND METHODS}

Experimental design. Assays of Caribbean sponges were performed with individuals of Echinaster echinophorus collected from cuts in the back-reef mangrove habitat at Sweetings Cay, Bahamas, and of Echinaster sentus collected from the mangrove habitat adjacent to Blackwater Sound near Key Largo, Florida, USA in May to October 1996, 1997). Echinaster spp. were collected only in mangroves in these areas, but they also inhabit Caribbean reefs (Clarke \& Downey 1992), so it is relevant to test preferences of Echinaster spp. for both mangrove and reef sponges. Sea stars were maintained in tanks of flowing seawater, and fed ad libitum on the sponge Hymeniacidon heliophila, but were not fed 1 to $2 \mathrm{~d}$ before performing a feeding assay. Pairwise assays of whole sponge tissue of 6 species of mangrove sponges (Tedania ignis, Dysidea etheria, Haliclona hogarthi, Ircinia felix, Chondrilla nucula, and Chondrosia collectrix) and 5 species of reef sponges (Callyspongia vaginalis, Geodia neptuni, Amphimedon compressa, Ecytoplasia ferox, and Agelas clathrodes) were performed to determine and compare feeding preferences for both E. echinophorus and E. sentus within these 2 groups of sponges. Pairwise assays of organic extracts from the same 2 groups of sponges were performed with E. echinophorus, with the hypothesis that similar preference hierarchies for whole tissues and organic extracts would indicate that secondary metabolites affect feeding preferences of $E$. echinophorus, while different preference hierarchies would suggest that other factors determine feeding preferences. Assays of organic extracts, spicules, and whole sponge skeleton were tested versus untreated controls to determine how each of these sponge constituents affects feeding by $E$. echinophorus. Whole tissue assays of chemically undefended mangrove and reef sponges (as determined by assays with E. echinophorus of foods containing organic extracts versus control foods) were performed with $E$. sentus to investigate whether feeding preferences for these sponges are affected by either nutritional content or skeletal components. Each sea star was used only once in each type of assay for each comparison.

Whole tissue assays. Whole tissue assays were performed at the National Undersea Research Center in 
Key Largo, in three 575 l outdoor fiberglass tanks provided with constantly flowing seawater from the adjacent boat canal. Sponges were collected from either the reefs or mangrove swamps and maintained in 1 tank. Small pieces (approx. $2 \mathrm{~cm} \times 2 \mathrm{~cm} \times 2 \mathrm{~cm}$ ) of sponge tissue were cut from the colonies with a scalpel to minimize tissue damage. When possible, areas that protruded from the sponge colony were used so that most of the piece removed was covered with intact ectoderm. The sponge pieces were held in flowing seawater for $>1$ to $2 \mathrm{~h}$ prior to assaying to minimize the chance that the sea stars were feeding in response to an exudate of freshly cut sponge.

Individuals of either Echinaster echinophorus or E. sentus were held in one of several plastic dishes $(12 \mathrm{~cm}$ diam., $5 \mathrm{~cm}$ deep) connected to frames of PVC pipe that kept the dishes floating near the tops of the fiberglass tanks. A pair of sponges was placed in the bottom of the dish, held in place by small plastic cable ties with the cut side of the sponge facing down. The position of the sponges was alternated between dishes to prevent chemotaxic responses by the sea stars from affecting which sponge was chosen. The sea star was placed between the 2 sponges with 1 arm extended toward, but not touching, each sponge. After $1 \mathrm{~h}$, the choice of each sea star was recorded. Feeding behavior was defined as the sea star being motionless with its central disk centered over some portion of the sponge. Whether each sea star had its gut everted was also recorded. Results of preferences for each pair of sponges were analyzed by a 2-tailed binomial test (Sokal \& Rohlf 1981). Sea stars that did not choose either sponge were not used in statistical analyses. Feeding preference hierarchies were inferred from the results.

Extract and skeletal assays. Assays of sponge extracts and sponge skeletal components were performed at the wet laboratory of the University of North Carolina at Wilmington at Wrightsville Beach, NC, USA. Specimens of Echinaster echinophorus were maintained in $155 \mathrm{l}$ aquaria with a constant flow of sand-filtered seawater. Each aquarium was divided into 5 cells with 1 sea star in each cell. Crude organic extracts were isolated by sequentially extracting sponge tissue in methanol and 1:1 methanol:dichloro-
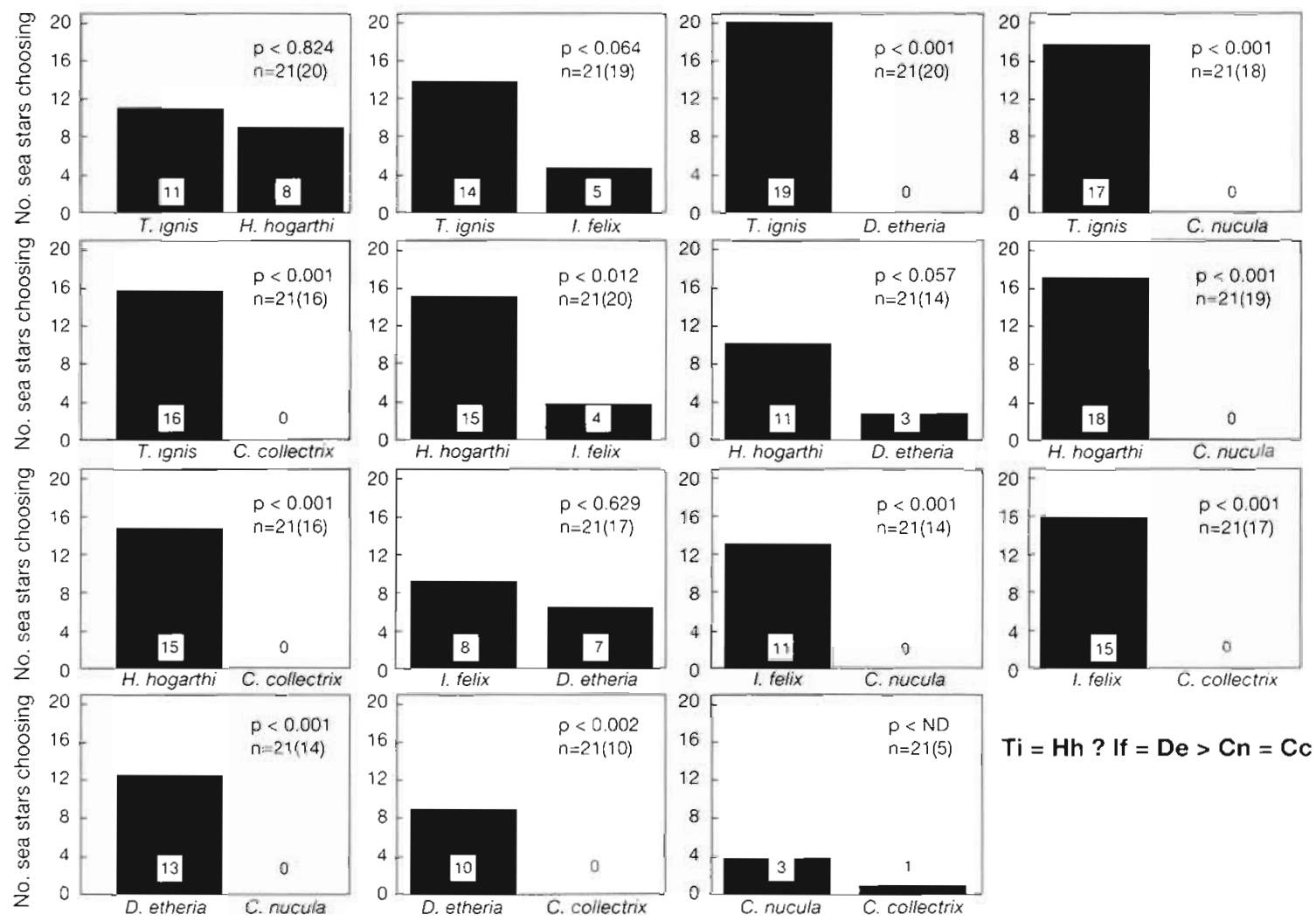

$\mathrm{Ti}=\mathrm{Hh} ? \mathrm{If}=\mathrm{De}>\mathrm{Cn}=\mathrm{Cc}$

Fig. 1. Aquarium feeding assays using the sea star Echinaster echinophorus offered whole tissue of the mangrove sponges Tedania ignis (Ti), Dysidea etheria (De), Haliclona hogarthi (Hh), Ircinia felix (If), Chondrilla nucula (Cn), and Chondrosia collectrix (Cc). Bars represent number of sea stars exhibiting feeding behavior. Numbers in bars represent number of sea stars with gut everted (see 'Materials and methods'). $\mathrm{n}$ = number of sea stars used in assay (number of sea stars used in statistical analyses). p-values calculated by 2 -tailed binomial tests. $\mathrm{P}<\mathrm{ND}=$ sample size too small to calculate $\mathrm{p}$-value. Preference hierarchy inferred from pairwise test is given at lower right 

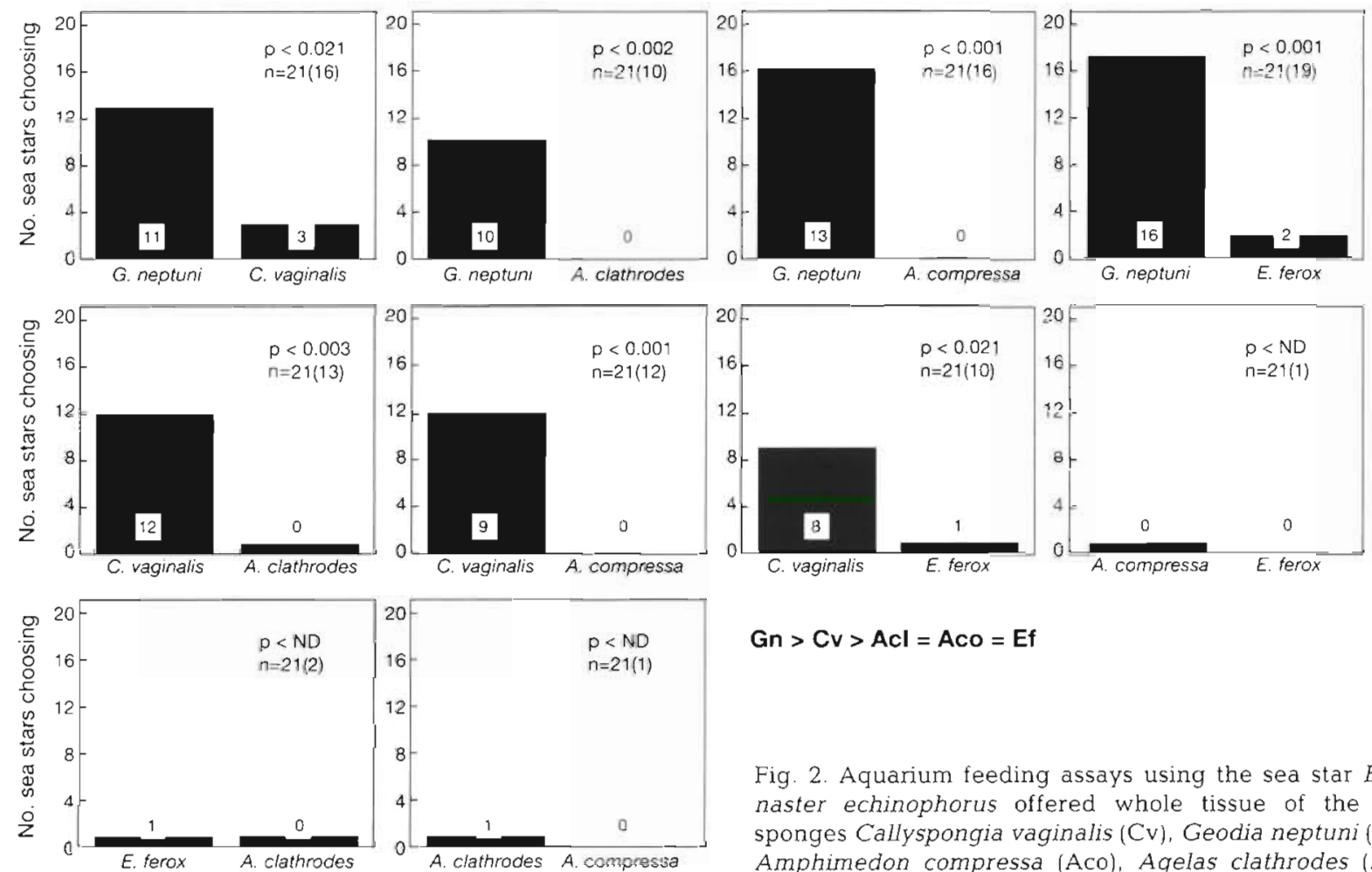

\section{$\mathrm{Gn}>\mathrm{CV}>\mathrm{ACl}=\mathrm{ACO}=\mathrm{Ef}$}

Fig. 2. Aquarium feeding assays using the sea star Echi. naster echinophorus offered whole tissue of the reef sponges Callyspongia vaginalis ( $\mathrm{Cv})$, Geodia neptuni $(\mathrm{Gn})$, Amphimedon compressa (Aco), Agelas clathrodes (Acl), and Ectyoplasia ferox (Ef). Bars represent number of sea stars exhibiting feeding behavior. Numbers in bars represent number of sea stars with gut everted (see 'Materials and methods'). $\mathrm{N}=$ number of sea stars used in assay (number of sea stars used in statistical analyses). P-values calculated by 2 -tailed binomial tests. $\mathrm{P}<\mathrm{ND}=$ sample size too small to calculate $\mathrm{p}$-value. Preference hierarchy inferred from pairwise test is given at lower right

methane for 12 to $24 \mathrm{~h}$ each, filtering the combined extracts through diatomaceous earth, and drying off the solvents by rotary evaporation and vacuum concentration. Spicules were obtained by completely oxidizing sponge tissue with household bleach $15.25 \%$ sodium hypochlorite). Whole sponge skeleton (spongin + spicules) was isolated by extracting and lightly bleaching lyophilized sponge tissue as described in Chanas \& Pawlik (1996).

Pairwise assays of crude organic extracts of reef and mangrove sponges were performed with Echinaster echinophorus. Extracts were incorporated into artificial food using the screen-based feeding assay of Hay et al. (1994). The artificial food was a mixture of lyophilized, powdered squid mantle and carrageenan that approximates the mean protein content of sponge tissue (see Waddell \& Pawlik 2000). A screen strip with food patches from the pair of sponges to be assayed, one on each end of the strip, was placed in a cell with an individual of E. echinophorus. The sea star was placed on the screen with its central disk over the clear screen in the middle and 1 arm extended out over each food patch. Sea stars did not consume the food patches, but did exhibit feeding behavior as described above, so a choice could be determined. After $1 \mathrm{~h}$, feeding behavior and gut eversion by E. echinophorus were recorded for each sponge extract, and results were analyzed by a 2 -tailed binomial test. Feeding preference hierarchies were inferred from the results and were compared to preference hierarchies for whole tissue assays.

Assays of foods containing organic extracts, spicules, and spiculated spongin, each against control foods, were performed to determine whether any of these sponge characteristics deter feeding by Echinaster echinophorus. Organic extracts, spicules, and whole sponge skeleton were incorporated into foods as described in Waddell \& Pawlik (2000), and assays were run and analyzed as described earlier.

\section{RESULTS}

\section{Assays of whole sponge tissue}

Pairwise assays of feeding preferences of Echinaster echinophorus for mangrove sponges yielded a preference hierarchy of Tedania ignis = Haliclona hogarthi? Ircinia felix $=$ Dysidea etheria $>$ Chondrilla nucula $=$ Chondrosia collectrix (Fig. 1). The relationship between the first 2 groups is unresolved because $T$. ignis 

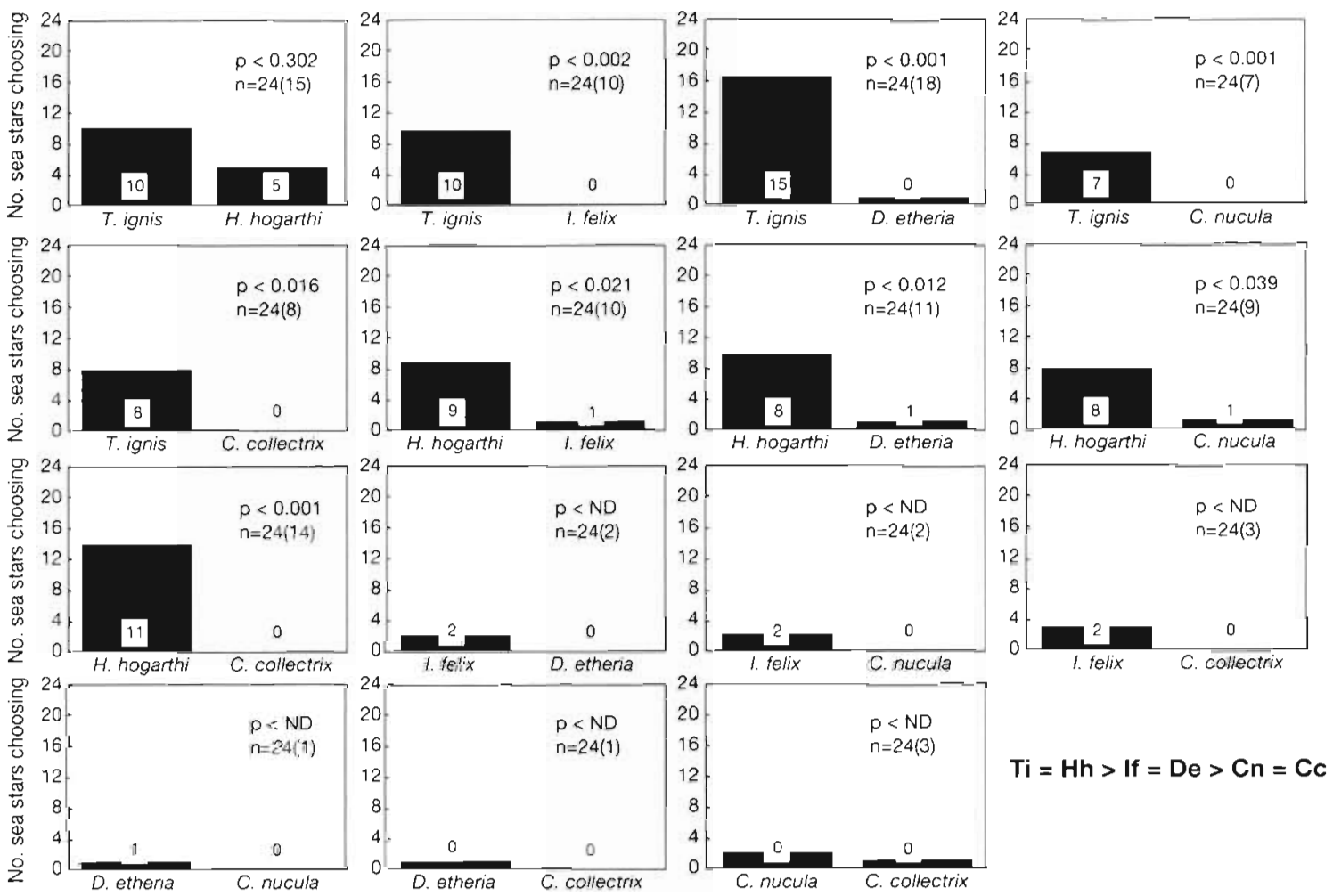

Fig. 3. Aquarium feeding assays using the sea star Echinaster sentus offered whole tissue of the mangrove sponges Tedania ignis (Ti), Dysidea etheria (De), Haliclona hogarthi (Hh), Ircinia felix (If), Chondrilla nucula (Cn), and Chondrosia collectrix (Cc). Bars represent number of sea stars exhibiting feeding behavior. Numbers in bars represent number of sea stars with gut everted (see 'Materials and methods'). $N=$ number of sea stars used in assay (number of sea stars used in statistical analyses). P-values calculated by 2 -tailed binomial tests. $\mathrm{P}<\mathrm{ND}=$ sample size too small to calculate p-value. Preference hierarchy inferred from pairwise test is given at lower right
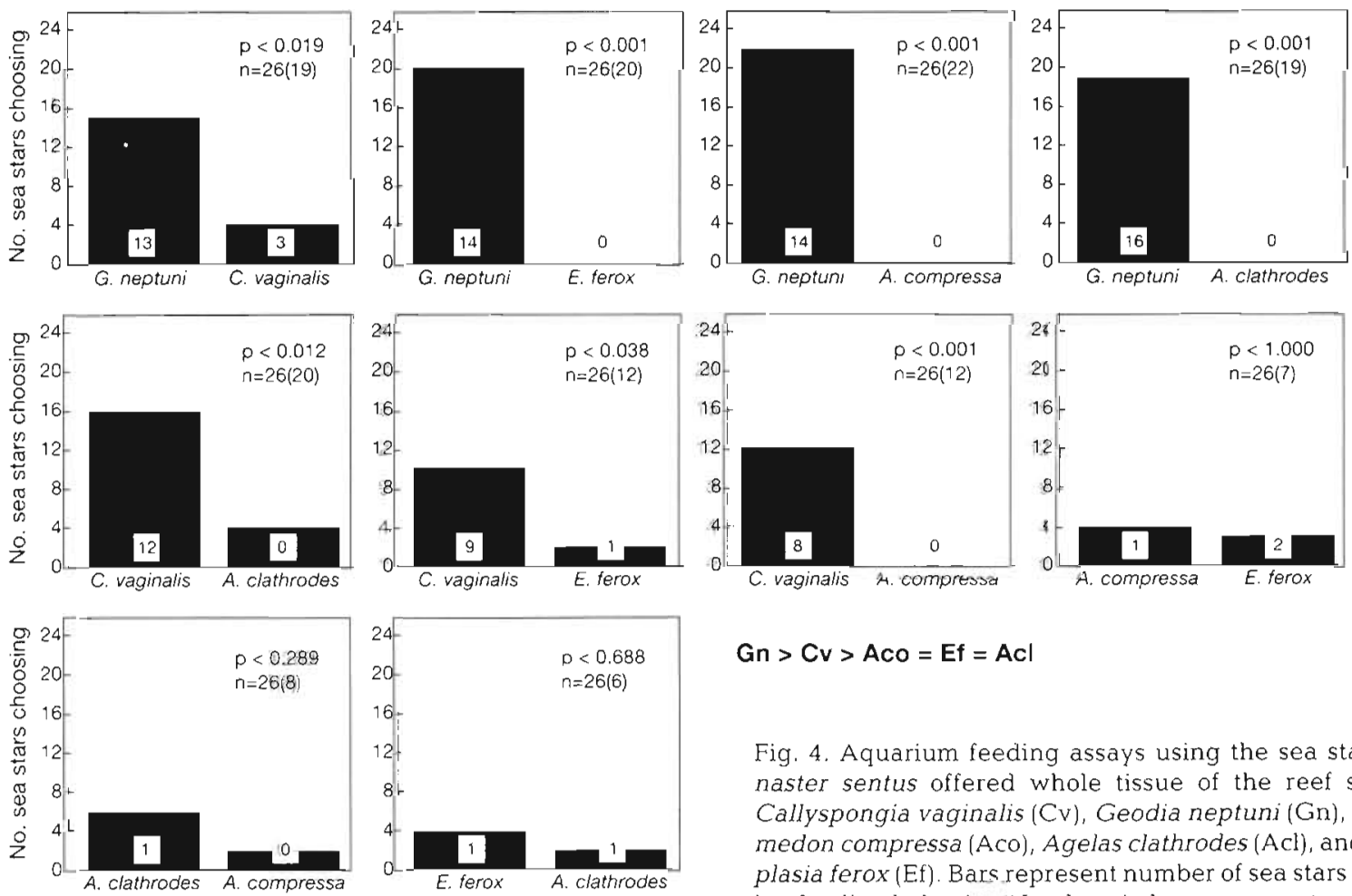

$\mathrm{Gn}>\mathrm{Cv}>\mathrm{ACO}=\mathrm{Ef}=\mathrm{ACl}$

Fig. 4. Aquarium feeding assays using the sea star Echinaster sentus offered whole tissue of the reef sponges Callyspongia vaginalis ( $\mathrm{Cv}$ ), Geodia neptuni (Gn), Amphimedon compressa (Aco), Agelas clathrodes (Acl), and Ectyoplasia ferox (Ef). Bars represent number of sea stars exhibiting feeding behavior. Numbers in bars represent number of sea stars with gut everted (see 'Materials and methods'). $N$ = number of sea stars used in assay (number of sea stars used in statistical analyses). P-values calculated by 2 -tailed binomial tests. Preference hierarchy inferred from pairwise test is given at lower right 
was preferred over $D$. etheria, but not over I. felix, while $H$. hogarthi was preferred over $I$. felix, but not over D. etheria. All 4 were preferred over C. nucula and C. collectrix. Similar assays for reef sponges yielded a preference hierarchy of Geodia neptuni > Callyspongia vaginalis $>$ Amphimedon compressa $=$ Ectyoplasia ferox = Agelas clathrodes (Fig. 2). G. neptuni was preferred over all other species, and $C$. vaginalis was preferred over all other species except $G$. neptuni.

Pairwise assays with Echinaster sentus yielded similar results. Assays of mangrove sponges yielded a hierarchy of Tedania ignis $=$ Haliclona hogarthi $>$ Ircinia felix $=$ Dysidea etheria $=$ Chondrilla nucula $=$ Chondrosia collectrix, with $T$. ignis and $H$. hogarthi being preferred over all other species (Fig. 3). Assays of reef sponges yielded a preference hierarchy identical to that for E. echinophorus (Fig. 4).

\section{Assays of crude organic extracts}

Pairwise assays with Echinaster echinophorus of crude organic extracts of mangrove sponges yielded a preference hierarchy different than that for whole sponge tissue: Tedania ignis = Ircinia felix? Chondrosia collectrix $=$ Chondrilla nucula $=$ Haliclona hogarthi $>$ Dysidea etheria (Fig. 5). I. felix, C. collectrix, and C. nucula all ranked higher than in the whole tissue hierarchy, while $H$. hogarthi and $D$. etheria ranked lower. The relationship between the first 2 groups is unresolved because $T$ ignis was preferred over $H$. hogarthi and C. collectrix, but not over C. nucula, while I. felix was preferred over $H$. hogarthi and $C$. nucula, but not over $C$. collectrix. All species were preferred over $D$. etheria.

Pairwise assays with Echinaster echinophorus of crude organic extracts of reef sponges yielded a preference hierarchy very similar to that for whole sponge tissue: Geodia neptuni $=$ Callyspongia vaginalis $>$ Amphimedon compressa = Ectyoplasia ferox $>$ Agelas clathrodes (Fig. 6). G. neptuni and C. vaginalis were preferred over all other species, while all species were preferred over $A$. clathrodes. In assays of crude organic extracts of mangrove sponges versus control foods, only the extract of Dysidea etheria significantly deterred feeding by E. echinophorus (Fig. 7). For reef sponges, extracts of $A$. compressa, E. ferox, and $A$. clathrodes all significantly deterred feeding by E. echinophorus (Fig. 8).
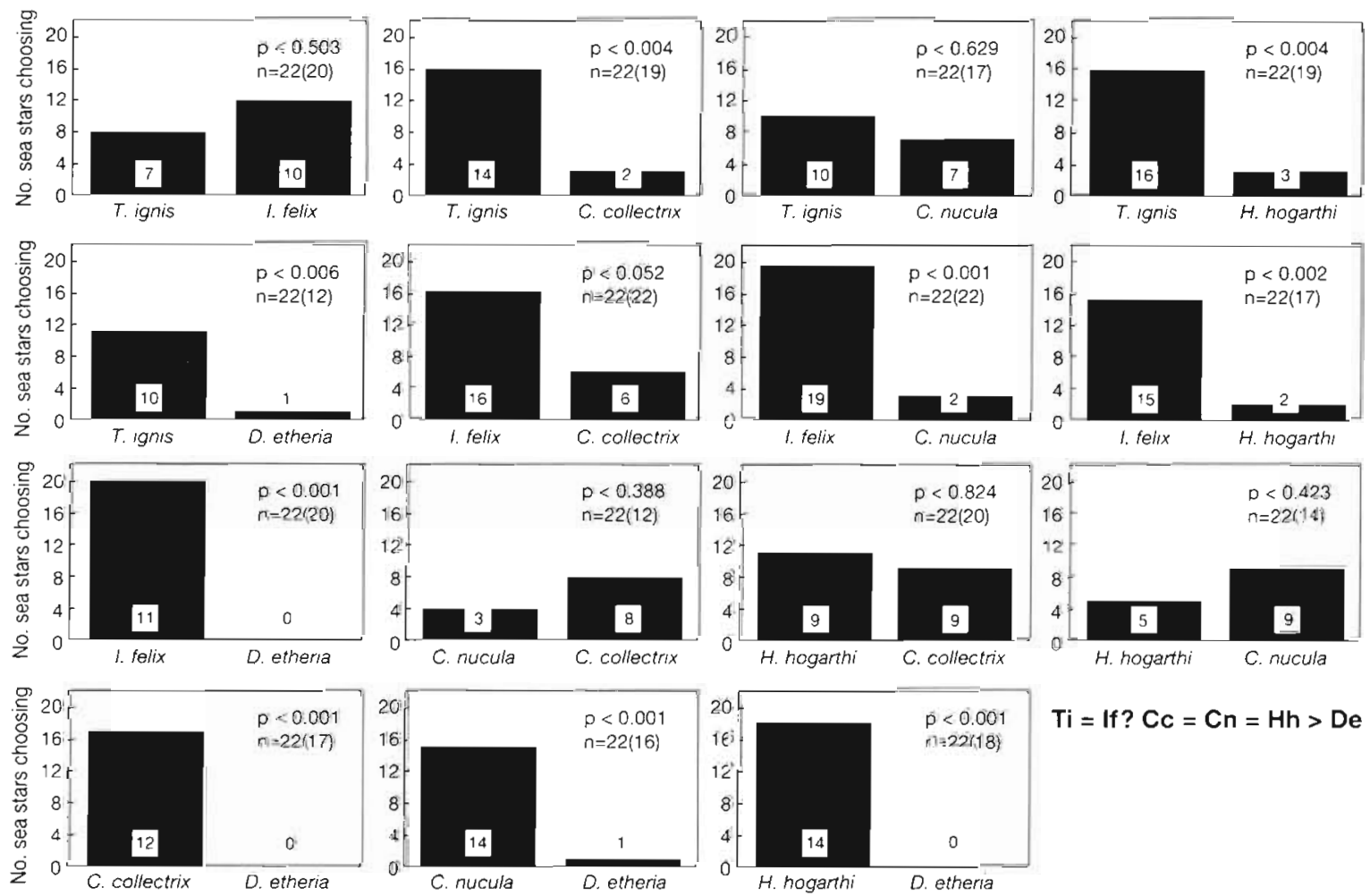

$\mathrm{Ti}=$ If $? \mathrm{Cc}=\mathrm{Cn}=\mathrm{Hh}>\mathrm{De}$

Fig. 5. Aquarium feeding assays using the sea star Echinaster echinophorus offered foods containing crude organic extracts of the mangrove sponges Tedania ignis (Ti), Dysidea etheria (De), Haliclona hogarthi (Hh), Ircinia felix (If), Chondrilla nucula (Cn), and Chondrosia collectrix $(\mathrm{Cc})$. Bars represent number of sea stars exhibiting feeding behavior. Numbers in bars represent number of sea stars with gut everted (see 'Materials and methods'). $\mathrm{N}=$ number of sea stars used in assay (number of sea stars used in statistical analyses). P-values calculated by 2 -tailed binomial tests. Preference hierarchy inferred from pairwise test is given at lower right. 

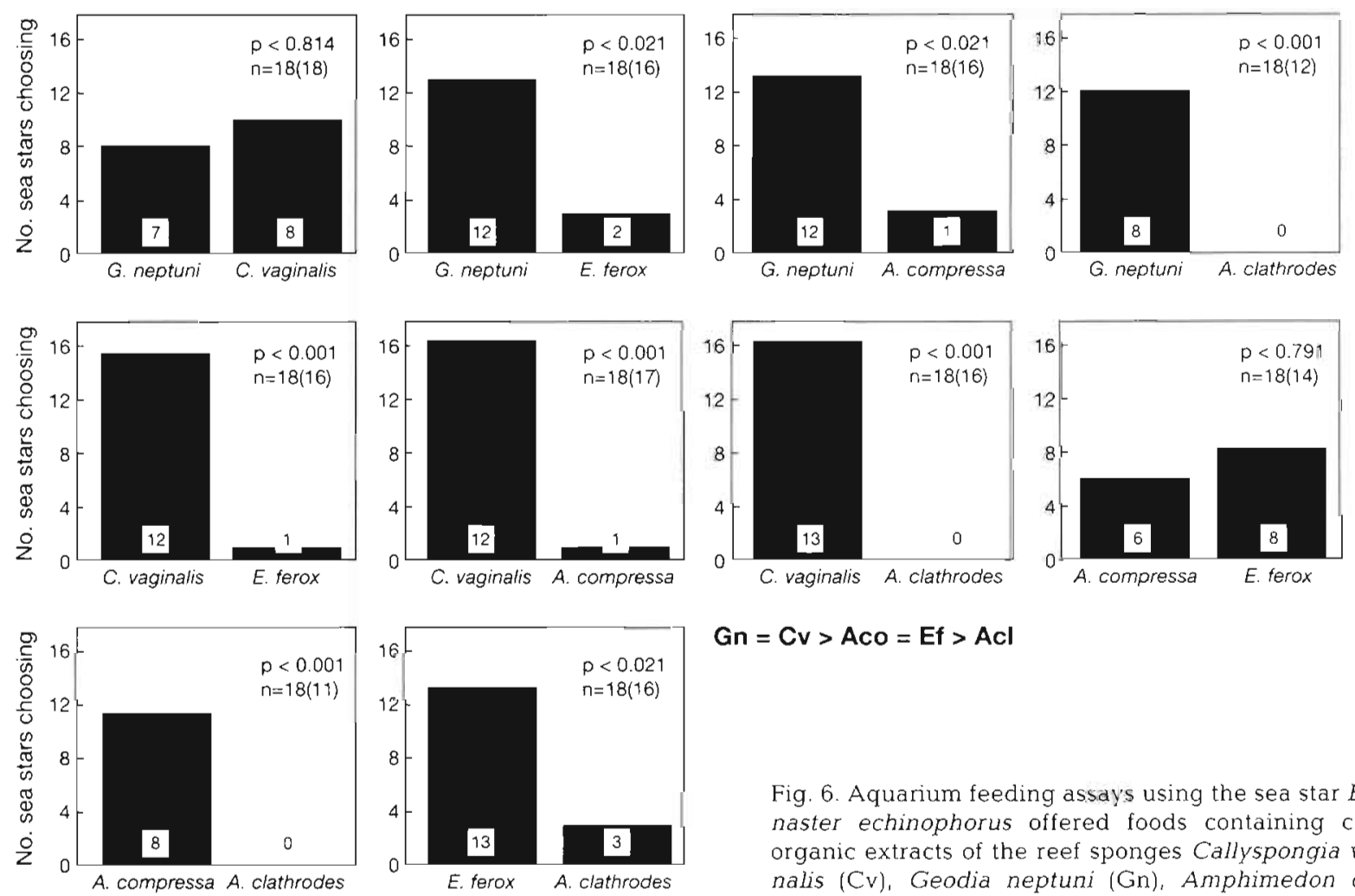

$\mathrm{Gn}=\mathrm{Cv}>\mathrm{AcO}=\mathrm{Ef}>\mathrm{Acl}$

Fig. 6. Aquarium feeding assays using the sea star Echinaster echinophorus offered foods containing crude organic extracts of the reef sponges Callyspongia vaginalis (Cv), Geodia neptuni (Gn), Amphimedon compressa (Aco), Agelas clathrodes (Acl), and Ectyoplasia ferox (Ef). Bars represent number of sea stars exhibiting feeding behavior. Numbers in bars represent number of sea stars with gut everted (see 'Materials and methods'). $N$ = number of sea stars used in assay (number of sea stars used in statistical analyses). P-values calculated by 2 -tailed binomial tests. Preference hierarchy inferred from pairwise test is given at lower right

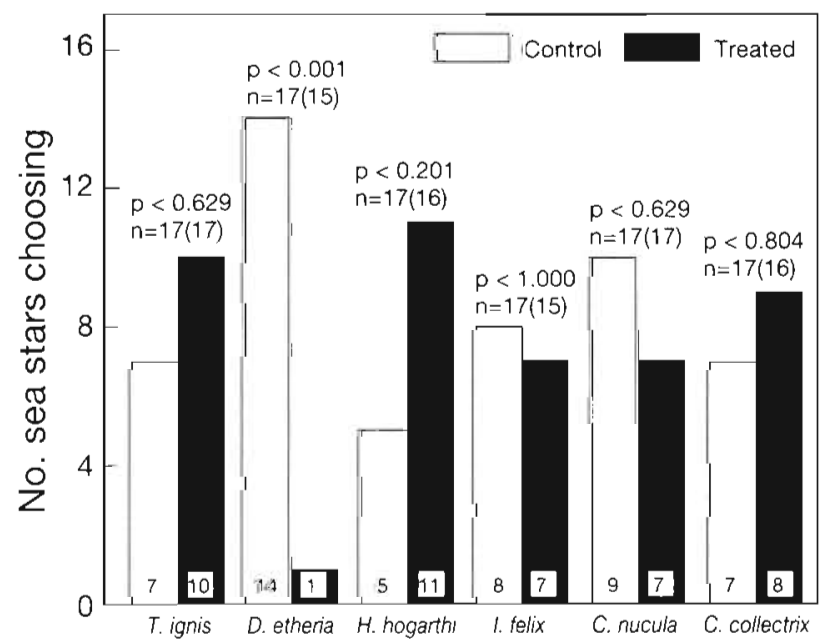

Fig. 7. Aquarium feeding assays using the seastar Echinaster echinophorus offered foods containing crude organic extracts of mangrove sponges versus control gels. Bars represent number of sea stars exhibiting feeding behavior. Numbers in bars represent number of sea stars with gut everted (see 'Materials and methods'). $\mathrm{N}=$ number of sea stars used in assay (number of sea stars used in statistical analyses). P-values calculated by 2 -tailed binomial tests. See Table 1 for full species names

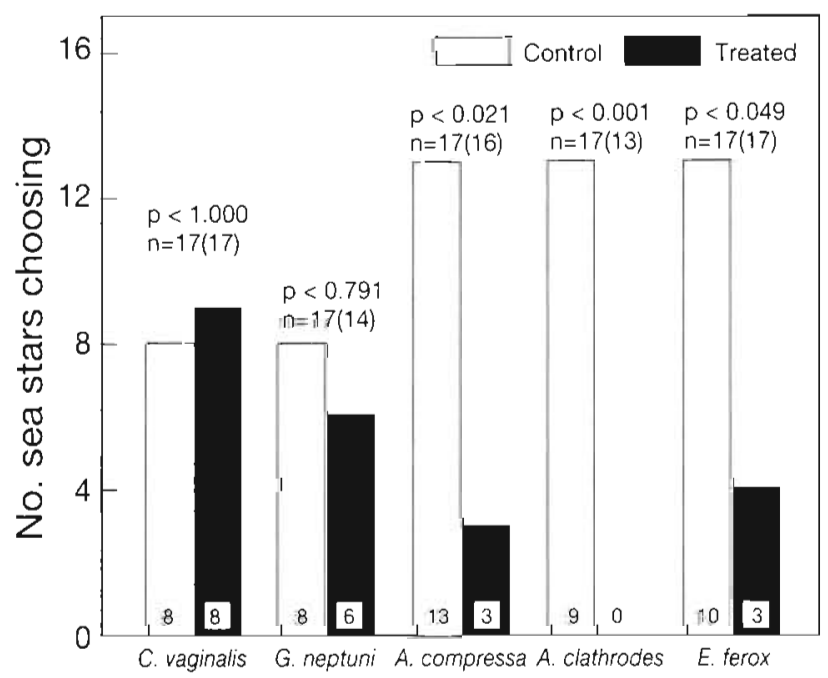

Fig. 8. Aquarium feeding assays using the sea star Echinaster echinophorus offered crude organic extracts of reef sponges versus control gels. Bars represent number of sea stars exhibiting feeding behavior. Numbers in bars represent number of sea stars with qut everted (see 'Materials and methods'). N = number of sea stars used in assay (number of sea stars used in statistical analyses). P-values calculated by 2 -tailed binomial tests. See Table 1 for full species names 


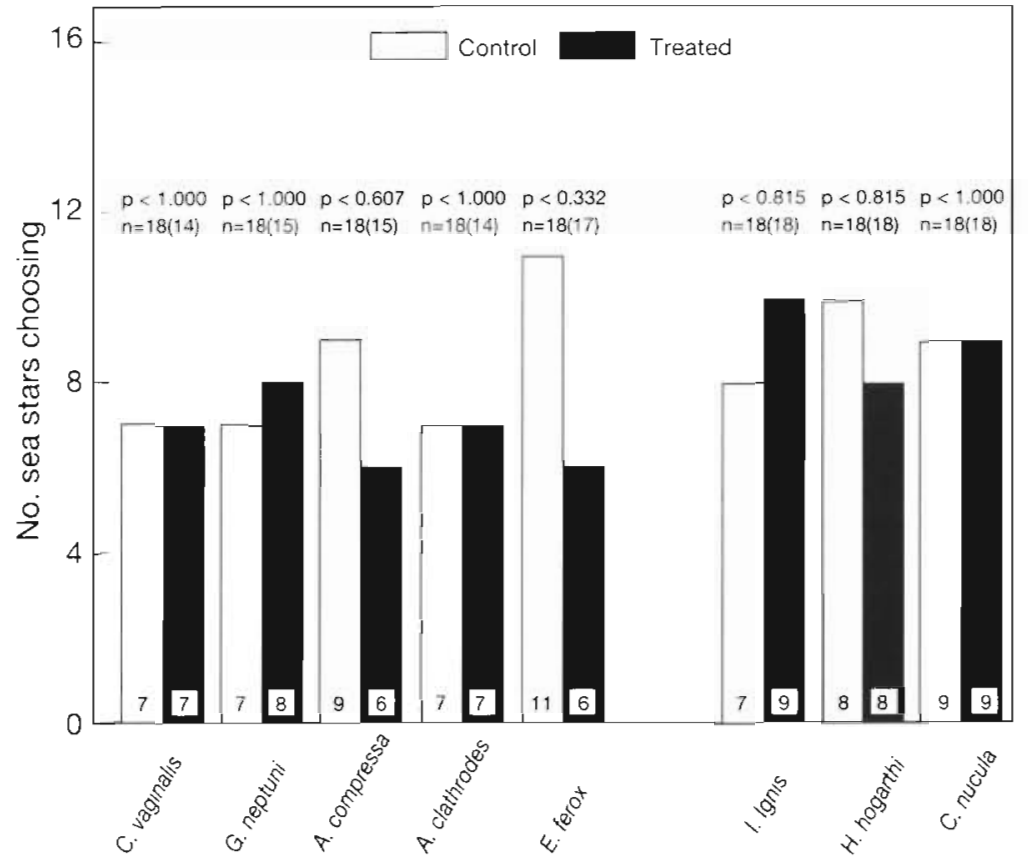

Fig. 9. Aquarium feeding assays using the sea star Echinaster echinophorus offered foods containing a natural concentration of sponge spicules versus control foods. Bars represent number of sea stars exhibiting feeding behavior. Numbers in bars represent number of sea stars with gut everted (see 'Materials and methods'). $N$ = number of sea stars used in assay (number of sea stars used in statistical analyses). P-values calculated by 2 -tailed binomial tests. See Table 1 for full species names

\section{Assays of spicules and whole sponge skeleton}

In assays of spicule treated foods versus control foods, spicules from 3 species of mangrove sponges (Tedania ignis, Haliclona hogarthi, and Chondrilla nucula) and from 5 species of reef sponges (Geodia neptuni, Callyspongia vaginalis, Amphimedon compressa, Ectyoplasia ferox, and Agelas clathrodes) did not deter feeding by Echinaster echinophorus (Fig. 9).

In assays of whole sponge skeleton (spicules + spongin) from 4 species of mangrove sponges (Tedania ignis, Ircinia felix, Chondrilla nucula, and Chondrosia collectrix), feeding by Echinaster echinophorus was not significantly reduced compared to control foods (Fig. 10).

\section{Assays of chemically undefended sponges}

The 3 species of mangrove sponges that yielded extracts that, on average, enhanced feeding in assays with Echinaster echinophorus (Tedania ignis, Haliclona hogarthi, and Chondrilla nucula; Fig. 7) and 2 species of reef sponges that yielded nondeterrent extracts (Geodia neptuni and Callyspongia vaginalis; Fig. 8) were subjected to whole tissue assays with $E$. sentus with the resulting preference hierarchy: $G$. neptuni $=T$. ignis $=C$. vaginalis? $H$. hogarthi > C. nucula (Fig. 11). The relationship between the first 2 groups is unresolved because $G$. neptuni was preferred over $H$. hogarthi, while $T$. ignis and $C$. vaginalis were not. All sponge species were preferred over $C$. nucula by $E$. sentus.

\section{DISCUSSION}

This study provides further evidence that chemical defenses are an important antipredatory strategy of Caribbean sponges and that sponge skeletal components do not serve an antipredatory function. The Caribbean sea stars Echinaster echinophorus and Echinaster sentus prefer the reef sponges Geodia neptuni and Callyspongia vaginalis and avoid feeding on Amphimedon compressa, Ectyoplasia ferox, and Agelas clathrodes (Figs. 2 \& 4). Pairwise assays using E. echinophorus of foods containing organic extracts of reef sponges produced the same feeding preference hierarchy (Fig, 6), and the organic extracts of $A$. compressa, E. ferox, and A. clathrodes deterred feeding
Fig. 10. Aquarium feeding assays using the sea star Echinaster echinophorus offered foods containing a natural concentration of whole sponge skeleton versus control foods. Bars represent number of sea stars exhibiting feeding behavior. Numbers in bars represent number of sea stars with gut everted (see 'Materials and methods'). $\mathrm{N}=$ number of sea stars used in assay (number of sea stars used in statistical analyses). P-values calculated by 2 -tailed binomial tests. See Table 1 for full species names 

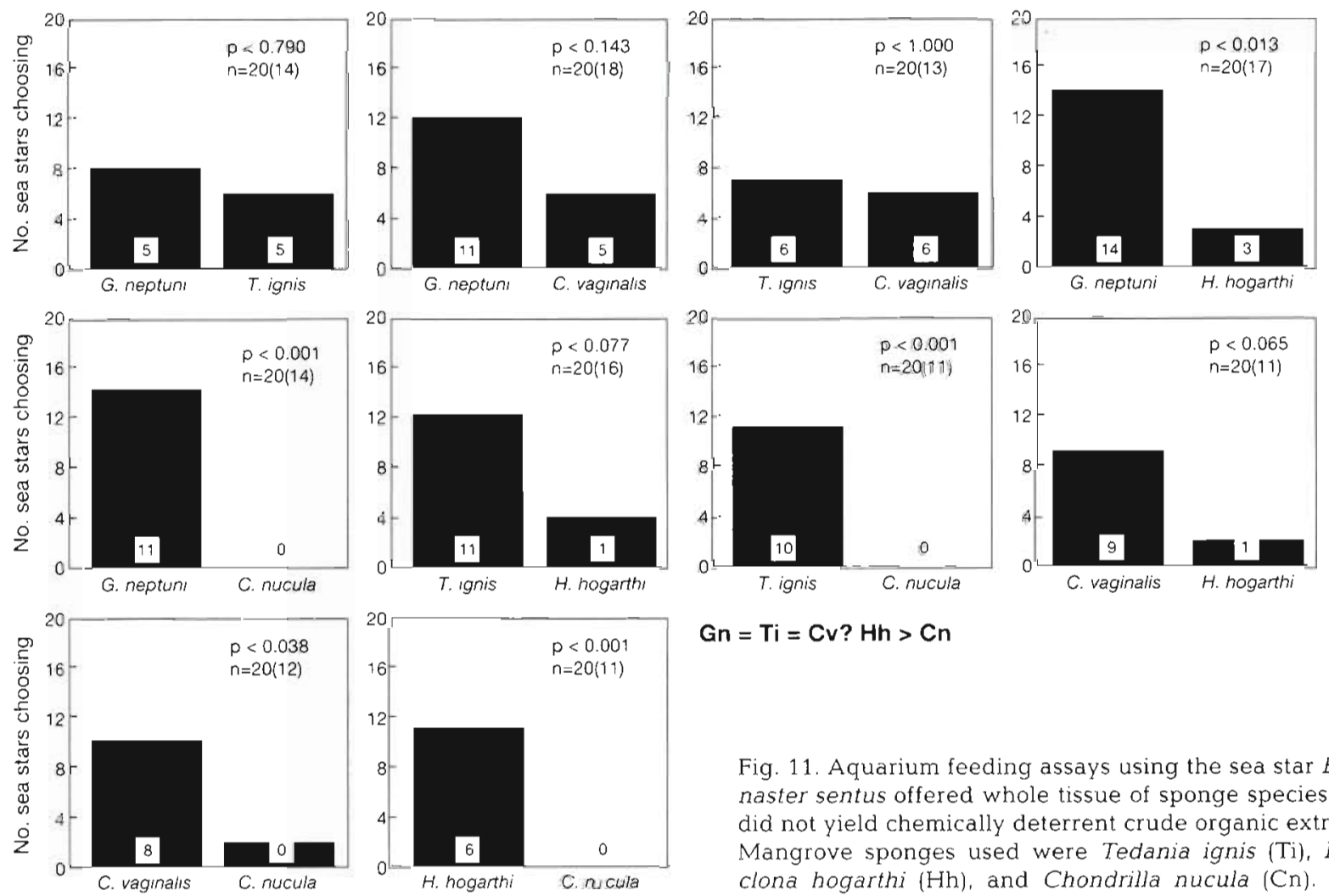

$\mathrm{Gn}=\mathrm{Ti}=\mathrm{Cv} ? \mathrm{Hh}>\mathrm{Cn}$

Fig. 11. Aquarium feeding assays using the sea star Echinaster sentus offered whole tissue of sponge species that did not yield chemically deterrent crude organic extracts. Mangrove sponges used were Tedania ignis (Ti), Haliclona hogarthi ( $\mathrm{Hh}$ ), and Chondrilla nucula ( $\mathrm{Cn}$ ). Reef sponges used were Callyspongia vaginalis (Cv) and Geodia neptuni $(\mathrm{Gn})$. Bars represent number of sea stars exhibiting feeding behavior. Numbers on bars represent number of sea stars with gut everted (see 'Materials and methods'). $\mathrm{N}$ = number of sea stars used in assay (number of sea stars used in statistical analyses). P-values calculated by 2 -tailed binomial tests. Preference hierarchy inferred from pairwise test is given at lower right

Fig. 12. Nutritional and skeletal content of chemically undefended reef sponges: $\mathrm{G}$ in $=$ Geodia neptuni, $\mathrm{Ti}=$ Tedania ignis, $\mathrm{Cv}=\mathrm{Cally}$ spongia vaginalis, $\mathrm{H}, \mathrm{h}=$ Haliclona hogarthi, $\mathrm{Cn}=$ Chondrilla nucula $(\mathrm{R}=$ reef habitat, $\mathrm{M}=$ mangrove habitat). Sponges are listed from left to right in decreasing order of feeding preference of Echinaster sentus as determined from Fig. 11. Nutritional and skeletal content data adapted from Chanas \& Pawlik (1995). Protein, carbohydrate, lipid, and spicule (ash) content taken directly from Chanas \& Pawlik (1995). Spongin content estimated as: dry weight - extract weight - spicule (ash) weight from Chanas \& Pawlik (1995). Energy content of digestible tissue estimated as: (protein $\left.\times 18.8 \mathrm{~kJ} \mathrm{~g}^{-i}\right)+$ (carbohydrate $\times 16.7 \mathrm{~kJ} \mathrm{~g}^{-1}$ ) + (lipid $\times 39.7 \mathrm{~kJ} \mathrm{~g}^{-1}$ ). All values reported as $\mathrm{mg} \mathrm{ml}^{-1}$ wet sponge tissue, except energy as $\mathrm{kJ} \mathrm{ml}^{-1}$ wet sponge tissue
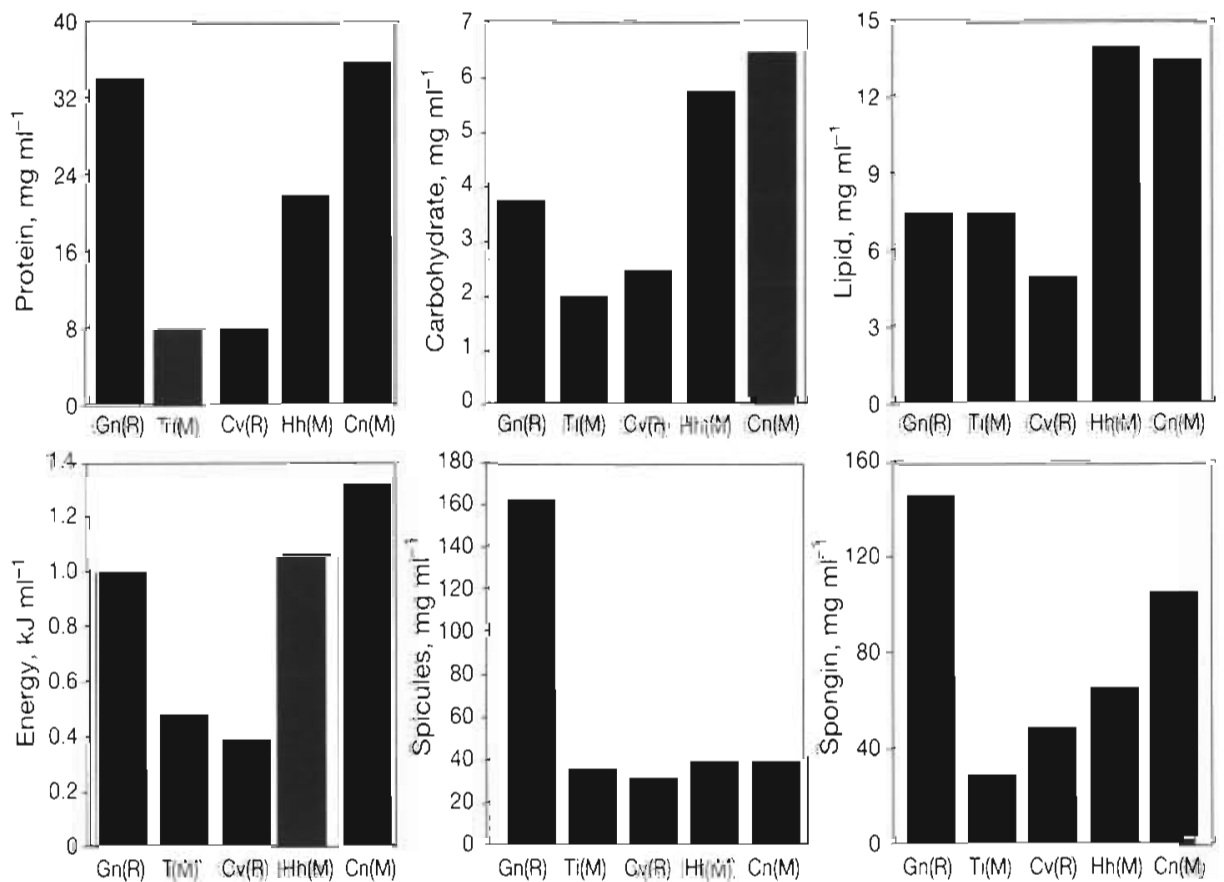
by E. echinophorus relative to control foods (Fig. 8), demonstrating that chemical defenses determine feeding preferences of $E$. echinophorus (and presumably $E$. sentus, because results of whole tissue assays were the same for both species) for this group of reef sponges. For mangrove sponges, both E. echinophorus and $E$. sentus preferred Tedania ignis and Haliclona hogarthi and avoided Chondrilla nucula and Chondrosia collectrix (Figs. 1 \& 3). For assays of foods containing organic extracts of mangrove sponges, however, E. echinophorus preferred foods containing extracts of $T$. ignis and Ircinia felix and avoided those containing extracts of Dysidea etheria (Fig. 5). We frequently encountered $E$. echinophorus feeding on $T$. ignis in the field, and $E$. echinophorus preferentially fed on foods treated with an extract of $T$. ignis over control foods. The extract of $D$. etheria deterred feeding by E. echinophorus relative to control foods (Fig. 7), which explains the relatively low position of $D$. etheria in the whole tissue preference hierarchy (Figs. $1 \& 3$ ). Extracts of $C$. nucula and C. collectrix did not deter feeding by $E$. echinophorus relative to control foods, so some factor besides chemical defense must cause avoidance of these sponges by Echinaster spp. (Fig. 7 ; see below). In assays with $E$. sentus of chemically undefended sponges from both reefs and mangroves, $G$. neptuni was most preferred, while C. nucula was least preferred (Fig. 11). The preferences of $E$. sentus for chemically undefended sponges have no apparent relationship with the mean contents of soluble (non-refractory) protein, carbohydrate, lipid, energy, spicules, or insoluble protein for these sponges (Fig. 12). C. nucula ranks high among chemically undefended sponges in soluble protein, carbohydrate, lipid, and energy content, yet is the least preferred food choice for $E$ sentus among chemically undefended sponges (Figs. 11 \& 12). In studies of spongivory by Antarctic sea stars, sponges with extracts that were toxic to goldfish when administered in suspension were typically avoided by sea stars, and preferences for non-toxic species did not correlate with biochemical composition (McClintock 1987). McClintock (1987) suggested that specific nutritional components of these sponges (i.e. vitamins, minerals, amino acids) may influence sea star feeding preferences. The results of the present study suggest that some other characteristic of sponges may also affect feeding preferences of Echinaster spp. In the case of $C$. nucula (and probably $C$. collectrix), the rubbery, slippery texture of the sponge surface may deter feeding by sea stars

Neither spicules (Fig. 9) nor whole sponge skeleton (Fig. 10) of Caribbean sponges deterred feeding by Echinaster echinophorus. It is also noteworthy that Geodia neptuni, one of the most preferred species, was also highest in both spicule and spongin content (Fig. 12). These results also agree with previous stud- ies of spongivory by Antarctic sea stars that found that neither spicule content nor refractory spongin content affected sea star preferences (Dayton et al. 1974, McClintock 1987), because sea stars can digest away sponge cellular material, leaving the skeleton intact (Dayton et al. 1974, Wulff 1995).

The data in this study on preferences of Echinaster spp. for Caribbean sponges agree with a study on spongivory by the Caribbean sea star Oreaster reticulatus (Wulff 1995). Callyspongia vaginalis and Ircinia felix were eaten by both Echinaster spp, and $O$. reticulatus, but Ectyoplasia ferox and Chondrilla nucula were avoided. Amphimedon compressa was avoided and Geodia neptuni was preferred by Echinaster spp., while $A$. erina and $A$. rubens were avoided and a cryptic, white Geodia sp. was eaten by $O$. reticulatus. No other sponge genera were common to both studies. These parallels suggest that similar factors influence the feeding preferences of both Echinaster spp. and $O$. reticulatus when feeding on Caribbean sponges.

The patterns of chemical deterrence of sponge organic extracts against Echinaster spp. also agree with studies of sponge chemical deterrence against generalist reef fishes (Pawlik et al. 1995) and against reef hermit crabs (Waddell \& Pawlik 2000; Table 1). Extracts of Amphimedon compressa, Ectyoplasia ferox, and Agelas clathrodes were deterrent to fish, hermit crabs, and sea stars, while the extracts of Callyspongia vaginalis were palatable to all 3 groups. Extracts of Dysidea etheria were deterrent and those of Haliclona hogarthi were palatable to both fishes and sea stars. Further similarities between fish and hermit crab assays are discussed in Waddell \& Pawlik (2000). It is reasonable to expect that the same secondary metabo-

Table 1. Comparison of deterrency of organic extracts of Caribbean sponges to fishes Thalassoma bifasciatum, hermit crabs Paguristes punticeps, and sea stars Echinaster echinophorus in aquarium feeding assays $+=$ consistently nondeterrent ${ }_{i}-=$ consistently deterrent $_{i} \mathrm{~V}=$ variably deterrent; $\mathrm{ND}=$ no data for that predator species. Fish data taken from Pawlik et al (1995). Hermit crab data taken from Waddell \& Pawlik (2000)

\begin{tabular}{|lccc|}
\hline Sponge & $\begin{array}{c}\text { Fish } \\
\text { assay }\end{array}$ & $\begin{array}{c}\text { Crab } \\
\text { assay }\end{array}$ & $\begin{array}{c}\text { Sea star } \\
\text { assay }\end{array}$ \\
\hline Agelas clathrodes & - & - & - \\
Amphimedon compressa & - & $\mathrm{V}$ & - \\
Callyspongia vaginalis & + & + & + \\
Chondrilla nucula & $\mathrm{V}$ & $\mathrm{V}$ & + \\
Chondroisa collectrix & + & $\mathrm{ND}$ & + \\
Dysidea etheria & - & $\mathrm{ND}$ & - \\
Ectyoplasia terox & - & - & - \\
Geodia neptuni & + & $\mathrm{V}$ & + \\
Haliclona hogarthi & + & $\mathrm{ND}$ & + \\
Ircinia felix & - & - & + \\
Tedania ignis & $\mathrm{V}$ & $\mathrm{ND}$ & + \\
\hline
\end{tabular}


lites are responsible for the antifeedant activity against all taxa of predators, because secondary metabolites are likely to be metabolically expensive (Paul 1992), and a sponge that could deter a diversity of predators with 1 compound would gain an advantage in fitness over one that needed to produce separate compounds to deter each predator. Algal secondary metabolites have been shown to deter both fishes and sea urchins, for example, but not amphipods (Hay et al. 1988). However, the micrograzer amphipods may gain protection from incidental predation by living on algae that are not eaten by macrograzers such as fishes. The amphipods would, therefore, occupy a different ecological niche from the macrograzers and should not be considered with fishes, sea urchins, hermit crabs, and sea stars. Among the macrograzers, patterns of chemical deterrency for both algae (Hay et al. 1988, 1994) and sponges (Pawlik et al. 1995, this study) seem to be analogous, and sponges may have micrograzers analogous to amphipods as well (Pawlik 1983). In the present study, some noteworthy exceptions to the foregoing generalities include crude extracts of Ircinia felix, which are palatable to sea stars but deterrent to fishes and hermit crabs, and extracts of Geodia neptuni, which are palatable to fishes and to sea stars but typically deterrent to hermit crabs. These sponge species may be good candidates for the isolation and identification of taxon-specific chemical feeding deterrents.

Acknowledgements. This research was made possible by funding from National Science Foundation grants OCE. 9314145 and OCE-9711255 (to J.R.P.); from NOAA/NURP grants UNCW9414, 9523, and 9709 (to J.R.P.); and from UNCW/CMSR Summer Research Fellowships in 1997 and 1998 (to B.W.). A number of people provided invaluable help throughout this project, particularly Greg McFall, Matt Dunlap, Sebastian Engel, Robyn Palmer, Monica Puyana, Joe Stack, Mariah Humphrey, Andy Rhyne, and Mike Baker Mark Hay gave valuable advice about performing the screen assays. We thank the captain and crew of the RV 'Seward Johnson' and the staff at the National Undersea Research Center at Key Largo, Florida. We thank the government of the Bahamas for permission to perform research in their territorial waters. This is contribution 242 from UNCW's Center for Marine Science Research

\section{LITERATURE CITED}

Albrizio S, Ciminiello P, Fattorusso E, Magno S, Pawlik JR (1995) Amphitoxin: a new high molecular weight antifeedant pyridinium salt from the Caribbean sponge Amphimedon compressa. J Nat Prod (Lloydia) 58:647-652

Birenheide R, Amemiya S, Motokawa T (1993) Penetration and storage of sponge spicules in tissues and coelom of spongivorous echinoids. Mar Biol 115:677-683

Bjorndal KA (1990) Digestibility of the sponge Chondrilla nucula in the green turtle, Chelonia mydas. Bull Mar Sci $47: 567-570$
Chanas B, Pawlik JR (1995) Defenses of Caribbean sponges against predatory reef fish. II. Spicules, tissue toughness, and nutritional quality. Mar Ecol Prog Ser 127:195-211

Chanas B, Pawlik JR (1996) Does the skeleton of a sponge provide a defense against predatory reef fish? Oecologia $107: 225-231$

Clark AM, Downey ME (1992) Starfishes of the Atlantic Chapman \& Hall, London

Dayton PK, Robilliard GA, Paine RT, Dayton LB (1974) Biological accomodation in the benthic community at McMurdo Sound, Antarctica. Ecol Monogr 44:105-128

Dunlap M, Pawlik JR (1996) Video-monitored predation by caribbean reef fishes on an array of mangrove and reef sponges. Mar Biol 126:117-123

Dunlap M. Pawlik JR (1998) Spongivory by parrotfish in Florida mangrove and reef habitats. PSZN 1: Mar Ecol 19: $325-337$

Faulkner DJ (1998) Marine natural products. Nat Prod Rep 15:113-158

Feder H, Christensen AM (1966) Aspects of asteroid biology In: Boolootian RA (ed) Physiology of Echinodermata. Interscience, New York, p 87-127

Ferguson JC (1969) Feeding activity in Echinaster and its induction with dissolved nutrients. Biol Bull 136:374-384

Hartman WD (1981) Form and distribution of silica in sponges. In: Simpson TL, Volcani BE (eds) Silicon and siliceous structures in biological systems. Springer, New York, p 454-493

Hay ME, Duffy JE, Fenical W, Gustafson K (1988) Chemical defense in the seaweed Dictyopteris delicatula: differential effects against reef fishes and amphipods. Mar Ecol Prog Ser 48:185-192

Hay ME, Kappel QE, Fenical W (1994) Synergisms in plant defenses against herbivores: interactions of chemistry, calcification, and plant quality. Ecology 75:1714-1726

Hendler G, Miller JE, Pawson DL, Kier PM (1995) Sea stars, sea urchins, and allies: echinoderms of Florida and the Caribbean. Smithsonian Institution Press, Washington, $\mathrm{DC}$

Jangoux M (1982) Food and feeding mechanisms: Asteroidea. In: Jangoux M, Lawrence JM (eds) Echinoderm nutrition. AA Balkema, Rotterdam, p 117-159

McClintock JB (1987) Investigation of the relationship between invertebrate predation and biochemical composition, energy content, spicule armament and toxicity of benthic sponges at McMurdo Sound, Antarctica. Mar Biol 94:479-487

McClintock JB, Baker BJ (1998) Chemical ecology of antarctic seas. Am Sci 86:254-263

McClintock JB, Baker BJ, Slattery M, Hamann M. Koptizke R, Heine $J$ (1994) Chemotactic tube-foot responses of a spongivorous sea star Perknaster fuscus to organic extracts from antarctic sponges. J Chem Ecol 20:859-870

Meylan A (1988) Spongivory in hawksbill turtles: a diet of glass. Science 239:393-395

Meylan A (1990) Nutritional characteristics of sponges in the diet of the hawksbill turtle, Eretmochelys imbricata. In: Rutzler K (ed) New Perspectives in sponge biology. Smithsonian Institution Press, Washington, DC, p $472-477$

Paul VJ (1992) Chemical defenses of benthic marine invertebrates. In: Paul V (ed) Ecological roles of marine natural products. Comstock Publishing, lthaca, NY, p 164-188

Pawlik JR (1983) A sponge-eating worm from Bermuda: Branchiosyllis oculata (Polychaeta, Syllidae). PSZN I: Mar Ecol 4:65-79

Pawlik JR (1993) Marine invertebrate chemical defenses. Chem Rev 93:1911-1922 
Pawlik JR, Kernan MR, Molinski TF, Harper MK, Faulkner DJ (1988) Defensive chemicals of the Spanish dancer nudibranch Hexabranchus sanguineus and its egg ribbons: macrolides derived from a sponge diet. J Exp Mar Biol Ecol 119:99-108

Pawlik JR, Chanas B, Toonen RJ, Fenical W (1995) Defenses of Caribbean sponges against predatory reef fish. I. Chemical deterrency. Mar Ecol Prog Ser 127:183-194

Randall JE, Hartman WE (1968) Sponge feeding fishes of the West Indies. Mar Biol 1:216-225

Scheuer PJ (1990) Some marine ecological phenomena chemical basis and biochemical potential. Science 248 : 173-177

Schiebling RE (1982) Feeding habits of Oreaster reticulatus (Echinodermata: Asteroidea). Bull Mar Sci 32:504-510

Sheild CJ, Witman JD (1993) The impact of Henricia sanguinolenta (O. F. Muller) (Echinodermata: Asteroidea)

Editorial responsibility: Otto Kinne (Editor),

Oldendorf/Luhe, Germany predation on the finger sponges, Isodictya spp. J Exp Mar Biol Ecol 166:107-133

Sloan NA (1.980) Aspects of the feeding biology of asteroids. Oceanogr Mar Biol Annu Rev 18:57-124

Sokal. RR, Rohlf FJ (1981) Biometry, 2nd edn. WH Freeman \& Co, New York

Thomas L.P (1960) A note on the feeding habits of the West Indian sea star Oreaster reticulatus (Linnaeus). Q J Fla Acad Sci 23:167-168

Waddell B, Pawlik JR (2000) Defenses of Caribbean sponges against invertebrate predators. I. Assays with hermit crabs. Mar Ecol Prog Ser 195:125-132

Wainwright SA, Biggs WD, Currey JD, Gosline JM (1982) Mechanical design in organisms. Princeton University Press, Princeton

Wulff JL (1995) Sponge-feeding by the Caribbean starfish Oreaster reticulatus. Mar Biol 123:313-325

Submitted: May 14, 1999; Accepted: October 13, 1999

Proofs received from author(s): March 8, 2000 